\title{
Requisites of a Good Investment
}

\author{
By Albert W. Atwood \\ Princeton, New Jersey
}

\section{Suitable Investments for the Masses}

T $\mathrm{T}$ is the purpose of this brief article 1 to consider a few essential factors of the problem of providing suitable investments for the masses of the people. I am not concerned with the investment problem of the businessman, so-called, or of the more prosperous professional. The important question which the country must face is that of inducing the great bulk of its wage earners to save. Provided they do save what then is to become of their funds?

\section{Opportenities Offered}

\section{Speculative Stocks}

It must be agreed and admitted at the outset that the small investor should not risk or speculate with his funds. This is hard doctrine because the little fellow likes to take a chance as well as the big one. Indeed the promoters of dubious stocks make out a specious but alluring argument for financial democracy, one might say, when they offer oil or mining stocks that promise fabulous returns.

"Why labor for years?" they ask. Why put your money into cold vault like repositories? What the average man wants is not a repository for his money, but a good thing. Bankers, financial writers and advisers-all these tell you to put your money in the savings bank. Why not take a try at fortune? The millionaire made his money by taking big chances, and by making lucky strikes. I will give you a chance at the same game."

Not until the offering of speculative stock to people of small means is widely recognized as charlatanism of the worst kind will much progress be made in spreading sound investments among the masses. I refer of course to promiscuous, miscellaneous stock offerings, and not to the purchase of shares in recognized, established transportation and industrial companies directly by the worker in those companies. It would be a hard doctrine indeed that the masses, most of whom are destined to remain wage earners all their lives, should never invest except in low interest bearing securities.

\section{Profit Sharing}

The opportunity for profit making on the part of the wage earner, aside from what is technically known as profit sharing, may come, and in increasing numbers of cases probably will come, through the purchase of stock in the company for which he works.

\section{Government Securities}

Cannot this whole problem of suitability and adaptability of investments for the people be treated in a brief, simple manner? Is it not solely a matter of degree? By that I mean that disadvantages such as risk, inconvenience, lack of marketability and the like in return for which the owner expects larger profits, should be assumed in increasing measure 
only as the investor progresses in wealth.

Elimination of Risk.-The poorer the investor the fewer "outs" should there be to his investments. The wealthier the investor the more chances can he afford to assume in return for the possibility of large gains. This is a simple principle, an $\mathrm{A} \mathrm{B} \mathrm{C}$ of the subject, but I think that even among experts its practical applications are often overlooked.

I.et us start with the young married man, the workman or clerk of twentyseven years, with a wife and one or two children. What should he invest in? Obviously in government savings stamps or in a good, strong savings bank. Frankly I do not think there is much choice between them. These two forms certainly come nearer to investment perfection for the young man of our imaginings than any other.

In either case he has a high degree of security, although of course the savings stamp of the government is safer theoretically than the savings bank. But for practical purposes it is well known that certain classes of savings banks are sufficiently free from risk. In other words the young clerk will not lose his hard won savings in either place. That is the first consideration. There is of course the Postal Savings Bank, but I take it that with the higher rate of interest paid upon government savings stamps and upon savings bank deposits there is no advantage in urging the merits of Postal Savings.

Convenience.--In the next place the stamps and the savings banks, or rather the certificates which are built up upon a collection of stamps, offer great convenience in the matter of deposit and withdrawal. There is not only convenience but freedom in these matters; also sufficient privacy. This applies both to the elements of time and of amount. Finally there is freedom from taxation.

Limits of Government Securities and Savings Accounts.--How any sane and honest person can urge the wage earner to invest elsewhere until he has at least enough in the savings bank or in government securities of a non-fluctuating character to meet sudden emergencies I cannot conceive. Further let me say that I do not regard these two forms of investment as wholly synonymous and interchangeable. The wage earner should (if he lives where there is a savings bank) have both. The government stamps or certificates are the safest investment on earth, but it would be a mistake for the wage earner to put several hundred dollars into them and none into the bank. For the savings bank account gives him a standing in the community, and affords him advantages when it comes to making loans and obtaining information regarding business or financial subjects which the government securities do not afford. A savings bank account, to be quite frank about it, has ulterior advantages which the government securities lack.

\section{Life Insurance}

Next in order for the worker who has dependents is life insurance. This, I think, is too obvious to require elaboration. Often it is well to keep on buying life insurance up to large sums, many thousands of dollars in fact, before any other investment whatever is even considered. Why waste time talking about the relative advantages of public utility bonds as against preferred industrial stocks for, let us say, a bookkeeper when we 
know perfectly well that if he should die his family would be in dire want. It is utter piffle, and I think that a large part of the efforts of stock brokers and bond houses, or investment bankers, to win the small investor are entirely injurious and pernicious. These people that are sought out are still in many cases about twenty thousand dollars below the point where they should become direct investors at all. They are still in the life insurance stage.

Somewhere along here the clerk with the wife and child should be taught to open a regular checking bank account, for the convenience which it affords and also for the standing which it gives him in the community.

Having acquired a good little nest egg in the form of a savings bank deposit orgovernment savings stamps, or both; having taken out ample life insurance and opened a bank account big enough to take care of current bills, then the young man had better consider the purchase of Liberty bonds and a home. I refer of course to piping times of peace and not to war times when to purchase a Liberty bond is an essential of patriotism.

Certainly the clerk should not buy even a Liberty bond any earlier in his financial progress than this, because the bond is subject to market fluctuation and no one is warranted in urging upon him the risks of the market until he has various back logs of the kind already described. As for a home, the wisdom of its purchase depends of course to some extent upon the young man's location, upon whether his job is reasonably permanent and other similar considerations. But generally speaking it is a good investment and pays dividends of family happiness and good citizenship which cannot be expected of a bond or stock in a corporation of which the owner hardly knows the name.

\section{Building and Loan Associations}

Next let our clerical friend look into the building and loan in his town or the credit union, if there is one, in his own office. Or perhaps his firm is offering stock to its employees. This is the one case where he can judge direct investments. Of course many employees do not like to buy stock in the concern for which they work because they fear it will tie them to their present employer or because it may give the employer an excuse to reduce their wages. But if these dangers are guarded against, if the independence of the worker is in no way infringed upon by a stock selling arrangement, or if the worker prefers to stay in one place and cast in his lot more or less permanently with one concern, then the more widely the custom of inducing employees to invest in the business. the better.

With many thousands of workers, especially of the clerical and more highly skilled classes, I see no reason why investment should take any other form after the more primary requirements already referred to have been taken care of. Of course I recognize the danger of possible abuse. Fly-bynight concerns might enlist their employees' money and decamp with it. But even the more ignorant worker can form a fair judgment as to whether the concern which employs him is of that variety.

Certainly he can form a hundred times better judgment than of a concern for which he does not work. And the corporations which have 
offered stock to employees thus far and then of stocks. But I feel that have in most cases been highly suc- there is no such hurry to educate the cessful. A concern must be fairly small investor in direct participation stable before it can really make any in corporate bonds and stocks as many headway in such financing.

If our clerk still goes on earning enough for further investment-if he feels he has put all that is safe in his own concern or if his employer does not offer him stock - then let him study outside offerings, first of bonds experts insist. After the young man has provided for himself in the manner here briefly outlined then there will be time enough to consider the bewildering variety of direct investments, with their qualities, their suitabilities and adaptabilities. 